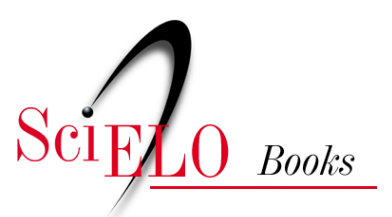

\title{
Reflexões \\ Por uma internet de qualidade
}

\author{
Nelson De Luca Pretto
}

PRETTO, N.D.L. Por uma internet de qualidade. In: Educações, culturas e hackers: escritos e reflexões [online]. Salvador: EDUFBA, 2017, pp. 104-105. ISBN: 978-85-232-2019-8.

https://doi.org/10.7476/9788523220198.0014.

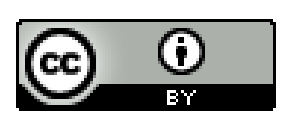

All the contents of this work, except where otherwise noted, is licensed under a Creative Commons Attribution $\underline{4.0 \text { International license. }}$

Todo o conteúdo deste trabalho, exceto quando houver ressalva, é publicado sob a licença Creative Commons Atribição 4.0.

Todo el contenido de esta obra, excepto donde se indique lo contrario, está bajo licencia de la licencia Creative Commons Reconocimento 4.0. 


\section{Por uma internet de qualidade}

Celebramos com foguetórios, no dia de São João, a entrada em vigor do Marco Civil da Internet, depois de mais de seis meses de imbróglio no Congresso Nacional. O Marco Civil funciona como uma espécie de "constituição" para a internet e só se tornou necessário por conta da ganância das operadoras de telecomunicações e das megacorporações, que passaram a controlá-la, transformando-a em algo totalmente diferente daquela internet em seus primeiros anos, na segunda metade do século passado. Ela nasceu com uma grande possibilidade de se estabelecer como uma comunicação horizontal todos-todos. No entanto, com o seu espantoso crescimento, as grandes corporações passaram a querer transformá-la num grande modelo de negócios, baseado na comunicação "de poucos para muitos".

O Marco brasileiro está servindo de inspiração para muitos países, em função dos avanços que aqui conseguimos, mas não se engane: a guerra não terminou!

Ao longo de mais de três anos, lutamos intensamente para construí-lo de forma democrática e participativa. Foram realizadas inúmeras as audiências/discussões públicas, presenciais e via rede, primeiro sob a batuta do Ministério da Justiça, depois pela Câmara dos Deputados, e, o tempo todo, por nós, ativistas das liberdades, na rede e fora dela. A campanha por uma legislação que não ferisse as liberdades individuais e não maculasse os princípios da internet foi intensa (marcocivil.com.br) e terminou, após um embate entre executivo e legislativo, com uma evidente e explícita pressão do grande capital ligado às telecomunicações e ao entretenimento. $\mathrm{O}$ que se queria era transformar a internet em um sistema similar à TV a cabo, onde se paga pelo que se consome. Pelo menos em parte, vencemos essa parada.

Tem mais. Relatório recentemente divulgado pela empresa Akamai mostra o que já sabíamos por experiência própria: piora a cada ano a qualidade da nossa banda larga. Também não anda a contento a 
implantação da banda larga no país e sem internet de qualidade não conseguimos avançar no uso da rede para a educação, saúde, para o desenvolvimento científico, tecnológico e a inovação.

No início de junho, no encontro anual de prefeitos americanos, eles foram explícitos: é necessário defender, com unhas e dentes, a neutralidade da rede, porque "uma internet aberta e livre é criticamente importante para a saúde das cidades americanas".

Desde os anos de 1990, quando a UFBA liderou a implantação da internet no Estado, lutamos para que a Bahia tivesse uma rede consistente, que conectasse todos os municípios, numa política integrada e integradora de todo o Estado. Tínhamos como parceiro o CADCT (embrião da FAPESB), mas os governos, desde aquela época e até hoje, não conseguiram ver a importância da montagem de um backbone público que conectasse os atuais 27 territórios.

Agora, esperamos, ante tantas evidências, aqui e acolá, uma tomada de consciência de que uma rede fortalecida é fundamental para o desenvolvimento e a inovação, ao mesmo tempo em que "permite a qualquer um ter a chance de interagir, participar e competir" (palavras dos prefeitos americanos), e que os nossos governantes façam algo de concreto para mudar essa realidade e, de fato, conectar a Bahia. Com a palavra os candidatos.

Publicado no jornal A Tarde, Salvador, em 7 de julho de 2014.

\section{Inclusão digital: "para sonhar muitos sonhos"}

"Hoje é um dia para sonhar muitos sonhos. Toda vez que nós, os povos indígenas, o povo primeiro desta terra, nos encontramos é dia para cele- 